[Med. Entomol. Zool. Vol. 52 No. 3 p. 195-200 2001]

\title{
ATPase activities of acarid mite, Tyrophagus putrescentiae (Schrank) (Acari: Acaridae), and their inhibition by several acaricides
}

\author{
Tomoyuki Hashimoto ${ }^{1)}$, Naoya TAKADA ${ }^{2)}$ and Naoki Motoyama ${ }^{3)}$ \\ ${ }^{1)}$ Department of Environmental Biology, Japan Environmental Sanitation Center, Yotsuyakamicho 10-6, \\ Kawasaki-ku, Kawasaki, 210-0828 Japan \\ ${ }^{2)}$ Department of Global Agricultural Sciences, Graduate School of Agriculture and Life Sciences, \\ University of Tokyo, Yayoi 1-1-1, Bunkyo-ku, Tokyo, 113-8657 Japan \\ ${ }^{3)}$ Laboratory of Pesticide Toxicology, Faculty of Horticulture, Chiba University, Matsudo 648, \\ Matsudo, 271-8510 Japan
}

(Received: 5 September 2000; Accepted: 19 July 2001)

\begin{abstract}
Key words: ATPase, acaricide, Tyrophagus putrescentiae, oligomycin, knock-down, immobilization
\end{abstract}

\begin{abstract}
Poisoning symptoms caused by three acaricides and one insecticide in the acarid mite, Tyrophagus putrescentiae (Schrank), were classified into two types, i.e. knock-down and immobilization. Since the immobilization was not preceded by hyper-excitation, convulsion or agony, an interference with the respiratory system was speculated. By analogy of certain acaricides known to produce similar poisoning symptoms in the two-spotted spider mite by inhibition of oligomycin-sensitive $(=\mathrm{OS})$ $\mathrm{Mg}^{2+}$ ATPase involved in the mitochondrial respiratory enzyme system, ATPase activities and their inhibition by several compounds in the acarid mite were investigated in vitro. The mitochondrial preparation exhibited the highest activity for $\mathrm{Na}^{+}-\mathrm{K}^{+}$ATPase, while the activity for OS $\mathrm{Mg}^{2+}$ ATPase was relatively low. Among several compounds tested, the selective acaricides, dicofol and cyhexatin, exhibited the highest inhibition of both ATPase activities. Bis (2,3,3,3-tetrachloropropyl) ether $(=\mathrm{S}-421)$ and $p p^{\prime}$-DDT also exhibited significant but less inhibition of the enzymes. However, there was no consistent trend implicating a relation between in vitro OS $\mathrm{Mg}^{2+}$ A TPase inhibition and the in vivo immobilization symptom, except dicofol. With dicofol, the highest inhibition of the enzyme activity coincided with the highest immobilization symptom.
\end{abstract}

\section{INTRODUCTION}

Certain acaricides, such as $(1 R, 2 R, 4 R)$ born-2-yl 2 thiocyanoacetate (=IBTA), phenyl salicylate and benzyl benzoate, exhibit mite specific toxicity against house dust mites with little insecticidal activity. In contrast, certain organophosphates and pyrethroids with good insecticidal activity exhibit low acaricidal activity (Hirakoso, 1989; Hashimoto et al., 1998, 1999). The contrasting response of the mites to these compounds suggests a possible difference in metabolism between the spe- cific acaricides and the organophosphates and pyrethroids. A difference in target site sensitivity between mites and insects is another possible factor that may cause the contrasting response. However, only limited information is available on the exact site of action for the most specific acaricides.

Hashimoto et al. (2000) classified several acaricides into immobilizer type and knock-down type from observations on the poisoning symptoms of the house dust mites. The immobilizing effect of certain acaricides against spider mites was also observed by other workers in a phytoph- 
agous mite (Carbonaro et al., 1986). These results implicate a possible interaction of the specific acaricides with the respiration system of the mites.

Certain insecticides are known as respiratory inhibitiors (Fukami, 1976). Particularly, the $\mathrm{F}_{0} \mathrm{~F}_{1}$ ATPase, referred to as oligomycin-sensitive (=OS) $\mathrm{Mg}^{2+}$ ATPase in the present paper, involved in the mitochondrial electron transport system is susceptible to inhibition by certain insecticides (Desaiah et al., 1973; Patil et al., 1979; Carbonaro et al., 1986; Cutcomp et al., 1984; Kadir and Knowles, 1991b).

In the present study, the poisoning symptoms in the acarid mite, Tyrophagus putrescentiae (Schrank) (= Tp), were examined following the in vivo application of three acaricides and one insecticide. ATPase activities and their in vitro inhibition by several acaricides were investigated assuming a possible effect on the mitochondrial electron transport system.

\section{Materials ANd Methods}

\section{Mites}

Tp was mainly used throughout the present study. The American house dust mite, Dermatophagoides farinae Hughes (= Df), and the two-spotted spider mite, Tetranychus urticae Koch (=Tu), were also used for comparison in a part of this study. Both Df and Tp were provided by the Tokyo Women's Medical College. Rearing and harvesting methods were the same as those of Hashimoto et al. (2000). A susceptible strain of $\mathrm{Tu}$ was reared on kidney-bean, Phaseolus vulgaris L., at Chiba University. The adult mites on the bean leaves were collected by a microaspirator.

\section{Chemicals}

The compounds used for toxicity tests and in vitro ATPase inhibition studies were: cyhexatin (purity: 99.3\%), dicofol (96.3\%), permethrin (95.1\%), benzyl benzo- ate and phenyl salicylate (analytical grade) (Kanto Chemical); fenitrothion (96.8\%) (Sumitomo Chemical); IBTA (89.0\%) and bis (2,3,3,3-tetrachloropropyl) ether (=S-421, 94.1\%) (Sankyo Chemical Industries); diethyltoluamid (= deet,regarded as 100\%) (Showa Denko); $p p^{\prime}$-DDT (= DDT, 100\%) (Kureha Chemical Industry). Oligomycin was purchased from Sigma Chemical and consisted of $61 \%$ oligomycin A, 27\% oligomycin B and 10\% oligomycin C. ATP-Na $\mathrm{Na}_{2}$ was a product of Oriental Yeast. Ouabain was purchased from Wako Pure Chemical Industries.

\section{Observations of poisoning}

To compare the poisoning symptoms produced by exposure to four compounds including dicofol, DDT, cyhexatin and IBTA, the conditions of the mite were observed under binoculars as described by Hashimoto et al. (2000). Twenty female adults of $\mathrm{Tp}$ were allowed to wander on the chemical residue in a glass vial $(2 \mathrm{mg}$ ai $/ 16 \mathrm{~cm}^{2}$ ) for $24 \mathrm{~h}$. The numbers of knocked down and immobilized mites were counted periodically up to $3 \mathrm{~h}$ after the release. The mortality was observed at $24 \mathrm{~h}$. Acetone served as a control.

\section{Preparation of ATPase source}

Mitochondrial fractions were prepared by the procedure of Kadir and Knowles (1991b) and used as ATPase source. Whole mites were homogenized in icecold buffer (pH 7.4) (ca. 40 mg wet weight/ $\mathrm{m} l$ ) consisting of $10 \mathrm{mM}$ MOPS, $10 \mathrm{mM}$ Tris, $0.01 \mathrm{mM}$ EDTA and $0.32 \mathrm{M}$ sucrose. Homogenates were centrifuged at 1,000 $\times$ $g$ for $10 \mathrm{~min}$ at $5^{\circ} \mathrm{C}$. Supernatants were centrifuged at $13,000 \times g$ for $30 \mathrm{~min}$ at $5^{\circ} \mathrm{C}$, and the sediments were resuspended in the buffer and used as the ATPase sources. The ATPase sources in the buffer were stored at $-20^{\circ} \mathrm{C}$ until used. Protein concentration of the ATPase sources was measured using Coomasie protein assay reagent (Pierce). 


\section{Determination of A TPase activity}

The ATPase activity was usually measured according to the method of Kadir and Knowles (1991b) with some modifications. To compare the activity of $\mathrm{Mg}^{2+}$, $\mathrm{Na}^{+}-\mathrm{K}^{+}$and $\mathrm{Ca}^{2+}-\mathrm{Mg}^{2+}$ ATPase among $\mathrm{Tp}$, Df and $\mathrm{Tu}$, the assays were carried out under the same conditions in terms of protein concentration, ATP concentration, incubation time and temperature. The $\mathrm{Mg}^{2+}$ ATPase activity was measured with the reaction mixture (final volume $1.0 \mathrm{~m} l, \mathrm{pH}$ 7.0) containing the ATPase source (100 $\mu \mathrm{g}$ protein $/ \mathrm{ml}$ ), $30 \mathrm{mM}$ MES, $30 \mathrm{mM}$ Tris, 160 $\mathrm{mM} \mathrm{KCl}, 5 \mathrm{mM} \mathrm{MgCl}_{2}, 0.1 \mathrm{mM}$ ouabain and $1 \mathrm{mM}$ ATP. The $\mathrm{Mg}^{2+}$ ATPase activity was further separated into oligomycinsensitive $(=\mathrm{OS})$ and -insensitive (=OIS) parts by adding $10 \mathrm{ng}$ oligomycin $/ \mathrm{m} l$ to the reaction mixture. The $\mathrm{Na}^{+}-\mathrm{K}^{+}$ ATPase activity was measured using the reaction mixture (final volume $1.0 \mathrm{ml}, \mathrm{pH}$ 7.0) containing the ATPase source as above, $30 \mathrm{mM}$ MES, $30 \mathrm{mM}$ Tris, $120 \mathrm{mM}$ $\mathrm{NaCl}, 20 \mathrm{mM} \mathrm{KCl}, 5 \mathrm{mM} \mathrm{MgCl}_{2}$, and $1 \mathrm{mM}$ ATP in the presence or absence of $0.1 \mathrm{mM}$ ouabain. The $\mathrm{Na}^{+}-\mathrm{K}^{+}$ATPase activity was an ouabain- sensitive component. The $\mathrm{Ca}^{2+}-\mathrm{Mg}^{2+}$ ATPase activity was measured with the reaction mixture (final volume $1.0 \mathrm{~m} l, \mathrm{pH} 7.4$ ) containing the ATPase source as above, $30 \mathrm{mM}$ MES, 30 $\mathrm{mM}$ Tris, $100 \mathrm{mM} \mathrm{KCl}, 5 \mathrm{mM} \mathrm{MgCl}_{2}, 0.1$ $\mathrm{mM} \mathrm{CaCl}, 0.1 \mathrm{mM}$ ouabain and $1 \mathrm{mM}$ ATP. Oligomycin for the $\mathrm{Mg}^{2+}$ ATPase and ouabain for the $\mathrm{Na}^{+}-\mathrm{K}^{+}$ATPase were preincubated for $15 \mathrm{~min}$ at $25^{\circ} \mathrm{C}$ before adding ATP. Following the addition of ATP the reaction mixture was incubated for additional $60 \mathrm{~min}$ at $25^{\circ} \mathrm{C}$. The ATPase activity was determined by monitoring the production of inorganic phosphate (Pi). The Pi was measured by the modified procedure of Goldenberg and Fernandez (1966). To stop the reaction, a $200 \mu l$ of the reaction mixture was mixed with $2 \mathrm{ml}$ of iron-TCA reagent containing 10\% (w/ v) trichloracetic acid (TCA) and 3\% ammonium iron (II) sulfate at room temperature for $20 \mathrm{~min}$. The color was developed by adding $250 \mu \mathrm{l}$ of molybdate reagent containing $4.4 \%$ ammonium molybdate tetrahydrate and $9 \% \mathrm{H}_{2} \mathrm{SO}_{4}$. After the 20 min-reaction, the absorbance at $660 \mathrm{~nm}$ was measured.

For inhibition of the OS $\mathrm{Mg}^{2+}$ ATPase and $\mathrm{Na}^{+}-\mathrm{K}^{+}$ATPase of Tp by acaricides, the reaction mixture was preincubated with an acaricide for $15 \mathrm{~min}$ at $25^{\circ} \mathrm{C}$ before the addition of ATP. The protein content in the reaction mixture was $200 \mu \mathrm{g}$ for the OS $\mathrm{Mg}^{2+}$ ATPase and $100 \mu \mathrm{g}$ for the $\mathrm{Na}^{+}-$ $\mathrm{K}^{+}$ATPase. Cyhexatin was dissolved in ethanol and the other inhibitors were dissolved in acetone. The final concentration of ethanol or acetone was $2.0 \%$ for the $\mathrm{Mg}^{2+}$ ATPase and $1.0 \%$ for the $\mathrm{Na}^{+}-\mathrm{K}^{+}$ and $\mathrm{Ca}^{2+}-\mathrm{Mg}^{2+}$ ATPase assay. The same amount of the organic solvents was used for control. The optimum ATP concentration for the OS $\mathrm{Mg}^{2+}$ and $\mathrm{Na}^{+}-\mathrm{K}^{+}$ATPase assay was selected based upon preliminary experiments without acaricides, i.e. 8 $\mathrm{mM}$ and $1 \mathrm{mM}$ for the OS $\mathrm{Mg}^{2+}$ and $\mathrm{Na}^{+}$ $\mathrm{K}^{+}$ATPase, respectively.

\section{RESUlts}

Table 1 shows poisoning symptoms in the progress of time and the mortality at $24 \mathrm{~h}$ when Tp was exposed to a dry film of three acaricides and one insecticide. Dicofol immobilized $92.5 \%$ at $3 \mathrm{~h}$ exposure. IBT A also immobilized $31.6 \%$ of the mites. Both acaricides produced similar symptoms without preceding excitation, convulsion, or agony. A clearly different symptom of poisoning was observed with DDT, which knocked down the mites with hyper-excitation. Cyhexatin resulted in 9.5\% immobilization and $11.2 \%$ knock-down by $3 \mathrm{~h}$ exposure. Only dicofol completely killed all the mites tested after $24 \mathrm{~h}$. The lethal activity of DDT was the lowest against $\mathrm{Tp}$.

Table 2 shows a comparison of various ATPase activities among 3 mite species. The $\mathrm{Na}^{+}-\mathrm{K}^{+}$ATPase activity was the highest in $\mathrm{Tp}$, while $\mathrm{Ca}^{2+}-\mathrm{Mg}^{2+}$ ATPase activity was the highest in the Df and Tu. The 
Table 1. Poisoning symptoms in progress of time following the application of four compounds in Tp.

\begin{tabular}{|c|c|c|c|c|c|c|c|c|c|c|}
\hline \multirow{2}{*}{$\begin{array}{c}\text { Compounds } \\
\text { applied } \\
\left(2 \mathrm{mg} / 16 \mathrm{~cm}^{2}\right)\end{array}$} & \multirow{2}{*}{ Symptom } & \multicolumn{8}{|c|}{$\%$ Knocked down and immobilized mites } & \multirow{2}{*}{$\begin{array}{c}\% \\
\text { Mortality } \\
\text { after } 24 \mathrm{~h}\end{array}$} \\
\hline & & 10 & 20 & 30 & 45 & 60 & 90 & 120 & $180 \mathrm{~min}$ & \\
\hline \multirow[t]{3}{*}{ IBT A } & KD & 0 & 2.6 & 2.6 & 5.3 & 5.3 & 5.3 & 5.3 & 5.3 & \\
\hline & IM & 0 & 18.4 & 26.3 & 23.7 & 31.6 & 34.2 & 31.6 & 31.6 & \\
\hline & Total & 0 & 21.1 & 28.9 & 28.9 & 36.8 & 39.5 & 36.8 & 36.8 & 55.3 \\
\hline \multirow[t]{3}{*}{ Dicofol } & $\mathrm{KD}$ & 0 & 0 & 0 & 0 & 2.5 & 2.5 & 0 & 0 & \\
\hline & IM & 0 & 7.5 & 20.0 & 57.5 & 65.0 & 82.5 & 82.5 & 92.5 & \\
\hline & Total & 0 & 7.5 & 20.0 & 57.5 & 67.5 & 85.0 & 82.5 & 92.5 & 100 \\
\hline \multirow[t]{3}{*}{ DDT } & KD & 0 & 0 & 7.7 & 7.7 & 10.3 & 23.1 & 28.2 & 28.2 & \\
\hline & IM & 0 & 0 & 0 & 0 & 0 & 0 & 0 & 0 & \\
\hline & Total & 0 & 0 & 7.7 & 7.7 & 10.3 & 23.1 & 28.2 & 28.2 & 17.9 \\
\hline \multirow[t]{3}{*}{ Cyhexatin } & KD & 0 & 0 & 4.8 & 4.8 & 4.8 & 11.9 & 14.3 & 11.9 & \\
\hline & IM & 0 & 0 & 2.4 & 2.4 & 0 & 0 & 4.8 & 9.5 & \\
\hline & Total & 0 & 0 & 7.1 & 7.1 & 4.8 & 11.9 & 19.0 & 21.4 & 52.4 \\
\hline
\end{tabular}

Values are the mean of 2 replicates.

KD, knock down; IM, immobilization; Mean mortality of control was $7.5 \%$.

Table 2. Comparison of various ATPase activities among three mite species.

\begin{tabular}{lccc}
\hline \hline \multirow{2}{*}{ ATPase } & \multicolumn{3}{c}{ Activity in $\mu$ mole $\mathrm{Pi} / \mathrm{h} / \mathrm{mg}$ protein } \\
\cline { 2 - 4 } & $\mathrm{Tp}$ & $\mathrm{Df}$ & $\mathrm{Tu}$ \\
\hline $\mathrm{OS}^{-} \mathrm{Mg}^{2+}$ & $1.57(0.21)$ & $1.09(0.06)$ & $1.34(0.15)$ \\
$\mathrm{OIS}^{-} \mathrm{Mg}^{2+}$ & $2.34(0.17)$ & $1.67(0.16)$ & $5.95(0.23)$ \\
$\mathrm{Na}^{+}-\mathrm{K}^{+}$ & $5.95(0.64)$ & $1.99(0.11)$ & $1.14(0.20)$ \\
$\mathrm{Ca}^{2+}-\mathrm{Mg}^{2+}$ & $3.50(0.29)$ & $2.41(0.41)$ & $6.77(0.52)$ \\
\hline
\end{tabular}

Values are the mean with standard devidation (SD) of 3 replicates.

ATPase preparation containing $100 \mu \mathrm{g}$ protein/ $\mathrm{m} l$ were incubated with $1 \mathrm{mM} \mathrm{ATP}$ for $60 \mathrm{~min}$ at $25^{\circ} \mathrm{C}$.

OS- $\mathrm{Mg}^{2+}$, oligomycin-sensitive $\mathrm{Mg}^{2+}$ ATPase; OIS$\mathrm{Mg}^{2+}$, oligomycin-insensitive $\mathrm{Mg}^{2+}$ ATPase, Tp, Tyrophagus putrescentiae; Df, Dermatophagoides farinae; Tu, Tetranychus urticae.

OS $\mathrm{Mg}^{2+}$ ATPase activity was relatively low regardless of the mite species. The ratio of $\mathrm{OS} \mathrm{Mg}^{2+}$ ATPase activity in the total $\mathrm{Mg}^{2+}$ ATPase activity was 40\%, 39\% and $18 \%$ for $\mathrm{Tp}$, Df and Tu, respectively.

Figure 1 shows the effect of ATP concentration on the ATPase activities in Tp. The OS $\mathrm{Mg}^{2+}$ ATPase activity increased with increase of the ATP concentration up to $8 \mathrm{mM}$. In conrast, the $\mathrm{Na}^{+}-\mathrm{K}^{+}$ATPase activity reached a plateau at $1 \mathrm{mM}$ ATP showing inhibition by excess ATP.
Figure 2 shows percent inhibition of the OS $\mathrm{Mg}^{2+}$ and $\mathrm{Na}^{+}-\mathrm{K}^{+}$ATPase by several compounds in Tp. The most potent inhibitor was dicofol against both OS $\mathrm{Mg}^{2+}$ and $\mathrm{Na}^{+}-\mathrm{K}^{+}$ATPase. Cyhexatin also yielded higher inhibition against the OS $\mathrm{Mg}^{2+}$ ATPase, though the S-421 and DDT produced less but significant inhibition for both ATPase.

\section{Discussion}

Hashimoto et al. (2000) reported that the poisoning symptoms in Tp and Df by acaricides were classified into immobilization and knock-down types. According to the study, IBTA, benzyl benzoate and deet were considered to be immobilizer-type compounds against $\mathrm{Tp}$. In the current study, dicofol also demonstrated the immobilizing effect. Because of the similarity in the symptom, these compounds seemed to have a common nature in the mode of action.

The mites treated with these compounds gradually lost their movement and reached a quiet death without hyperexcitation, convulsion, or agony. The latter symptoms are characteristic of organophosphates and pyrethroids which are 


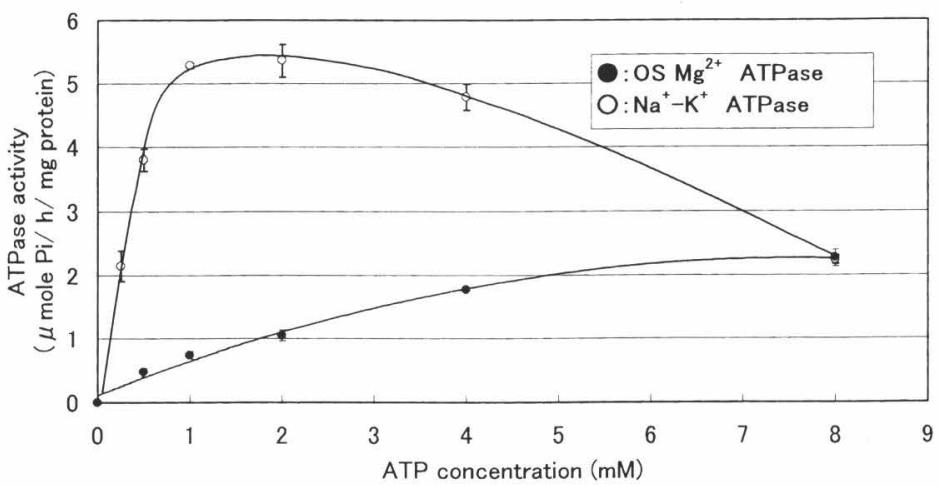

Fig 1. Effect of ATP concentration on OS $\mathrm{Mg}^{2+}$ ATPase and $\mathrm{Na}^{+}-\mathrm{K}^{+}$ATPase activities in Tp.

Values are the mean with standard deviation (SD) of 3 replicates. ATPase preparations (containing $200 \mu \mathrm{g}$ and $100 \mu \mathrm{g}$ protein $/ \mathrm{ml}$ for OS $\mathrm{Mg}^{2+}$ and $\mathrm{Na}^{+}-\mathrm{K}^{+}$ATPase, respectively) were incubated for 60 $\min$ at $25^{\circ} \mathrm{C}$.

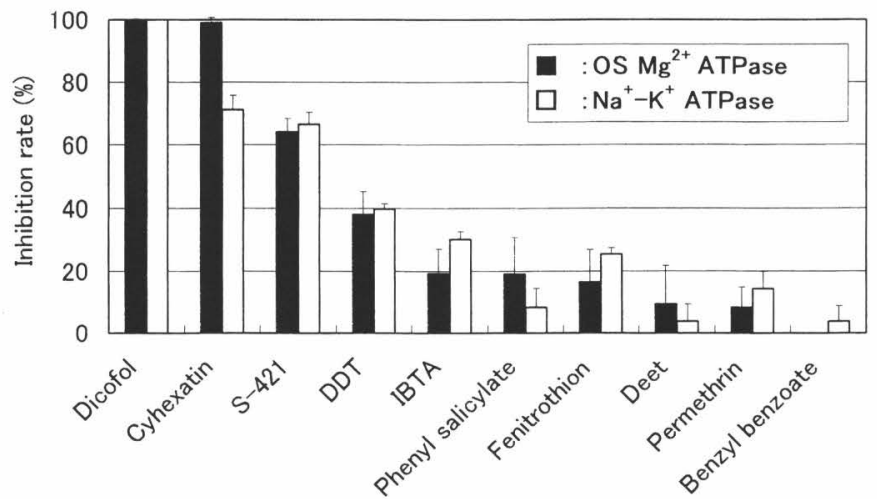

Fig 2. In vitro inhibition of $\mathrm{OS} \mathrm{Mg}^{2+} \mathrm{ATPase}$ and $\mathrm{Na}^{+}-\mathrm{K}^{+}$ATPase in $\mathrm{Tp}$ by several compounds including acaricides, insecticides, synergists and repellent.

Values are the mean with standard deviation (SD) of 3 replicates. ATPase preparations (containing $200 \mu \mathrm{g}$ and $100 \mu \mathrm{g}$ protein $/ \mathrm{m} l$ for $\mathrm{OS} \mathrm{Mg}^{2+}$ and $\mathrm{Na}^{+}-\mathrm{K}^{+}$ATPase, respectively) were preincubated with respective compounds at a final concentration of $100 \mu \mathrm{M}$ for $15 \mathrm{~min}$. OS $\mathrm{Mg}^{2+}$ and $\mathrm{Na}^{+}-\mathrm{K}^{+} \mathrm{ATPase}^{2}$ were incubated for additional $60 \mathrm{~min}$ at $25^{\circ} \mathrm{C}$ with $8 \mathrm{mM}$ and $1 \mathrm{mM} \mathrm{ATP}$, respectively.

known to interfere with the nervous transmission mechanisms in mites and insects. The immobilization and subsequent death produced by these acaricides in the present study suggested a possible interference with the respiratory system (Fukami, 1976). On the other hand, dicofol, cyhexatin, DDT, carbodiimides and oligomycin are known inhibitors of mitochondrial OS $\mathrm{Mg}^{2+}$ and $\mathrm{Na}^{+}-\mathrm{K}^{+}$ATPase (Desaiah et al., 1973; Patil et al., 1979; Chetty et al., 1984; Carbonaro et al., 1986; Kadir and Knowles, 1991a, b). Based upon these observations, a relation between the inhibition of ATPase activities and the im- mobilization symptom was postulated.

Dicofol and cyhexatin were found to be the most potent inhibitors against the OS $\mathrm{Mg}^{2+}$ and $\mathrm{Na}^{+}-\mathrm{K}^{+}$ATPase of Tp preparation, while S-421 and DDT also affected the ATPase activities to some extent. The ATPase inhibition by $\mathrm{S}-421$ coincided with the relatively high immobilizing effect observed in vivo against Tp (Hashimoto et al., 2000). However, the ratios of immobilized mites by DDT and cyhexatin were relatively low despite their high in vitro inhibitory potencies against ATPase activities. Furthermore, a high immobilizing effect was observed with benzyl ben- 
zoate and deet (Hashimoto et al., 2000), which showed only low ATPase inhibition rates in the present study. The inconsistent relation between the ATPase inhibition and the immobilization symptom may rule out the above postulation. In support of this conjecture, Kadir and Knowles (1991b) also observed the lack of the characteristic symptoms in the diamond back moth treated with two carbodiimides, both having high ATPase inhibition activity.

In the case of dicofol which showed both high ATPase inhibition and high immobilizing effect, however, further studies are required to examine the relation of the ATPase inhibition with the immobilization symptom.

\section{ACKNOWLEDGEMENTS}

Thanks are due to the staff of the Department of Environmental Biology and Dr. Ikuo Tanaka of Japan Environmental Sanitation Center for helpful suggestions.

\section{REFERENCES}

Carbonaro, M. A., Moreland, D. E., Edge, V. E., Motoyama, N., Rock, G. C. and Dauterman, W. C. 1986. Studies on the mechanism of cyhexatin resistance in the twospotted spider mite, Tetranychus urticae (Acari: Tetranychidae). J. Econ. Entomol., 79: 576579.

Chetty, S. C., Aldous, C. N. and Desaiah, D. 1984. Effect of temperature on the inhibition of rat brain synaptosomal ATPase by DDT and its structural analogs. J. Appl. Toxicol., 4: 194-197.

Cutcomp, L. K., Subramanyam, B. H. and Cheng, E. Y. 1984. Mitochondrial ATPase sensitivity to acaricides dicofol and tetradifon and susceptibility of spider mites. Indian J. Comp. Anim. Physiol., 2: 3742.

Desaiah, D., Cutcomp, L. K. and Koch, R. B. 1973. Inhibition of spider mite ATPase by Plictran and three organochlorine acaricides. Life Sci., 13: 1693-1703.

Fukami, J. 1976. Insecticides as inhibitors of respiration. In: Insecticide Biochemistry and Physiology (ed. Wilkinson, C.F.), pp. 353-396. Plenum Press, New York.

Goldenberg, H. and Fernandez. A. 1966. Simplified method for the estimation of inorganic phosphorus in body fluids. Clin. Chem., 12: 871-882.

Hashimoto, T., Minagawa, K., Mizutani, K. and Muraoka, R. 1998. Studies on acaricidal efficacy of some agents against a nuisance, Balaustium murorum (Acari: Erythraeidae). Pest Control Res., 13: 67- 72. Hashimoto, T., Motoyama, N. and Mizutani, K. 1999. Evaluation of the acaricidal efficacy of sixteen chemicals to three species of house dust mite, Dermatophagoides farinae, Tyrophagus putrescentiae and Blomia tropicalis, by filter paper contact method. Med. Entomol. Zool., 50: 349-354.

Hashimoto, T., Motoyama, N. Mizutani, K. and Shinjo, G. 2000. Repellent and lethal effect of seven chemicals on house dust mites, Dermatophagoides farinae Hughes (Acari: Pyroglyophidae) and Tyrophagus putrescentiae (Schrank) (Acari: Acaridae). Med. Entomol. Zool., 51: 275-281.

Hirakoso, S. 1989. Suppression effect on population growth of house dust mites by some acaricides. Pest Control Res., 4: 64-66.

Kadir, H. A. and Knowles, C. O. 1991a. Toxicological studies of the thiourea diafenthiuron in diamondback moths (Lepidoptera: Yponomeutidae), twospotted spider mites (Acari: Tetranychidae), and bulb mites (Acari: Acaridae). J. Econ. Entomol., 84: 780-784.

Kadir, H. A. and Knowles, C. O. 1991b. Inhibition of ATP dephosphorylation by acaricides with emphasis on the anti-ATPase activity of the carbodiimide metabolic of diafenthiuron. J. Econ. Entomol., 84: 801-805.

Patil, T. N., Telford, J. N., Plapp, F. W. and Koch, R. B. 1979. Isolation, characterization, and properties of Factor F1 from mitochondrial preparations of housefly (Musca domestica L.) thorax. Pestic. Biochem. Physiol., 12: 95-104. 